\title{
SISTEM PENDUKUNG KEPUTUSAN PEMILIHAN KARYAWAN TERBAIK MENGGUNAKAN METODE SIMPLE ADDITIVE WEIGHTING (Studi Kasus :PT. Bank Rakyat Indonesia Tbk. Divisi Layanan dan Contact Center Bagian Helpdesk)
}

\author{
Hafizh Qalam Ramadhan \\ Program Studi Teknik Informatika, Fakultas Teknik dan Ilmu Komputer, Universitas Indraprasta PGRI \\ Jalan Raya Tengah No 80, Kelurahan Gedong, Pasar Rebo, Jakarta Timur \\ hafizhqalamramadhan@gmail.com
}

\begin{abstract}
Abstrak
Karyawan merupakan aspek penting pada suatu perusahaan, dengan adanya karyawan yang memiliki standar kualitas yang baik maka daya produksi perusahaan tentu terus terjaga dan semakin meningkat. Untuk itu sangat penting untuk memberikan penghargaan terhadap karyawan yang berprestasi, khususnya pada karyawan PT. Bank Rakyat Indonesia Tbk. Divisi Layanan dan Contact Center Bagian Helpdesk. Demi memperoleh informasi yang cepat dan tepat terhadap kinerja karyawanmaka peneliti membuat sebuah sistem pendukung keputusan pemilihan karyawan dengan menggunakan metode Simple Additive Weighting (SAW). Sistem ini diharapkan mampu menentukan karyawan terbaik atas dasar kriteria yang ditentukan oleh perusahaan.
\end{abstract}

Kata Kunci :Sistem Pendukung Keputusan, Simple Additive Weighting, Pemilihan Karyawan Terbaik

\begin{abstract}
Employees are an important aspect in a company, with employees who have good quality standards, the company's production power will certainly continue to be maintained and increase. For that it is very important to give awards to employees who excel, especially employees of PT. Bank Rakyat Indonesia Tbk. Service Division and Contact Center Helpdesk Section. In order to obtain fast and accurate information on employee performance, researchers created a decision support system for employee selection using the Simple Additive Weighting (SAW) method. This system is expected to be able to determine the best employees based on the criteria determined by the company.
\end{abstract}

Keyword :decision support system, Simple Additive Weighting, The best employee selection

\section{PENDAHULUAN}

Karyawan merupakan salah satu Sumber Daya Manusia (SDM) yang digunakan sebagai alat penggerak dalam memajukan suatu perusahaan. Kinerja dari seorang karyawan dapat secara langsung mempengaruhi keuntungan yang didapat oleh perusahaan tersebut. Jika SDM dapat diorganisir dengan baik, maka perusahaan mampu menjalankan semua proses usahanya dengan baik. Tidak terkecuali bagi PT. Bank Rakyat Indonesia Tbk. Divisi Layanan dan Contact Center Bagian Helpdesk [1].

Persaingan di lingkungan kerja yang semakin kompetitif memacu PT. Bank Rakyat Indonesia Tbk. untuk berupaya lebih keras dalam meningkatkan kualitas kinerja karyawannya. Salah satu upaya dalam peningkatan kualitas kinerja tersebut dengan melakukan suatu pengukuran terhadap kinerja seorang karyawan terhadap perusahaan melalui suatu penilaian kinerja pegawai. Sayangnya belum ada suatu aplikasi yang mampu menentukan pemilihan karyawan terbaik secara cepat, tepat dan efisien. Sehubungan dengan hal tersebut, maka penulis membuat sebuah aplikasi sistem pendukung keputusan pemilihan karyawan terbaik berbasis java dengan metode Simple Additive Weighting (SAW) [2]. Aplikasi ini mampu menentukan karyawan terbaik atas dasar kriteria yang sudah ditentukan oleh perusahaan dimana nantinya ada inputan berupa nilai dari setiap kriteria dan masing-masing kriteria tersebut memiliki bobot yang berbeda [3]. Nantinya dari penilaian tersebut akan diolah dengan menggunakan metode simple additive weighting dan menghasilkan sebuah penilaian. Dengan adanya aplikasi ini diharapkan perusahaan mampu menentukan karyawan 
terbaik berdasarkan dengan kriteria yang sudah ditentukan dan dapat diakses secara cepat, tepat dan efisien.

\section{PENELITIAN RELEVAN}

Penelitian yang relevan dari Satria Abadi dan Febriani Latifah pada Tahun 2016 dengan judul Decission Support System Penilaian Kinerja Karyawan Pada Perusahaan Menggunakan Metode Simple Additive Weighting. Penilaian terhadap suatu pekerjaan dalam sebuah perusahaan merupakan suatu tahap evaluasi kerja yang dapat meningkatkan kualitas pekerjaan bagi kelangsungan aktivitas perusahaan didalamnya. Pekerjaan yang di inginkanoleh perusahaan terhadap para pekerja memiliki standart mutu untuk mengukur kebrhasilan kerja.Penilaian ini menggunakan metode Simple Additive Weighting (SAW) dalam sistem pendukung keputusan. Penilaian kinerja karyawan pada perusahaan didasari oleh beberapa kriteria yang telah ditetapkan, diantaranya kedisiplinan, kebersihan, kejujuran, komunikasi, kerjasama, dan tanggungjawab. Hasil dari penelitian ini berbentuk sebuah sistem pendukung keputusan yang dapat mengolah data pemilihan karyawan berprestasi menjadi sebuah pertimbangan yang valid. Berdasarkan hail dari penelitian yang telah dilakukan maka dapat disimpulkan bahwa alternatif A2 (Joni) merupakan karyawan berkinerja terbaik.Dari hasil penelitian tersebut diharapkan pengambil keputusan menjadi terbantu dalam menentukan karyawan mana yang berpretasi dalam suatu perusahaan atau instansi [4].

Penelitian yang relevan dari Fara Atika Tahun 2017). Sistem Pendukung Keputusan Pemilihan Guru Berprestasi di Kecamatan Kradenan Kabupaten Grobogan Menggunakan Metode SAW. Guru adalah panutan dalam dunia pendidikan yang aktif sebagai pendidik,pembimbing, penilai serta sebagai suri teladan terhadap anak didiknya. Label guru berprestasi merupakan salah satu cara untuk meningkatkan mutu dari kualitas pendidikan di Kecamatan Kradenan Kabupaten Grobogan. Banyaknya guru yang ada sulit untuk melakukan keputusan pemilihan guru berprestasi secara cepat dan tepat serta membutuhkan waktu yang lama dalam perhitungannya. Penelitian ini bertujuan untuk membuat suatu Decision Support System (DSS) dengan metode Simple AdditiveWeighting (SAW) berbasis web yang dirancang menggunakan Php HypertextPreprocessing (PHP), dan database $M y S Q l$ untuk mempermudah dalam pemilihan guruberprestasi secara cepat dan akurat tanpa membutuhkan waktu yang lama dalam perhitungannya [5].

\section{METODE PENELITIAN}

Metode yang digunakan dalan perancangan sistem untuk pemilihan karyawan terbaik adalah metode Simple Additive Weighting (SAW) karena metode ini umum digunakan dalam sebuah perhitungan dan metode yang sederhana serta mudah untuk dipahami karena memiliki algoritma yang tidak terlalu rumit.Menurut Frieyadie, F. (2016) konsep dasar metode Simple Additive Weighting adalah mencari penjumlahan berkualitas dari nilai kinerja pada setiap alternatif pada semua atribut Fishburn (1967) dan MacCrimmon (1968). Metode Simple Additive Weighting membutuhkan proses normalisasi matriks keputusan $(\mathrm{X})$ ke suatu skala yang dapat diperbandingkan dengan semua rating alternatif yang ada. Metode ini merupakan metode yang paling d dan paling banyak digunakan dalam menghadapi situasi Multiple Attribute Decision Making (MADM).

MADM merupakan suatu metode yang digunakan untuk mencari alternatif ideal dari sejumlah alternatif dengan kriteria tertentu. Metode Simple Additive Weighting ini mengharuskan pembuat keputusan menentukan kualitas bagi setiap atribut. Nilai total untuk alternatif diperoleh dengan menjumlahkan semua hasil perkalian antara nilai dan kualitas setiap atribut. Rating tiap atribut haruslah bebas dimensi dalam arti telah melewati proses normalisasi matriks sebelumnya. Proses pengambilan keputusan adalah memilih suatu altematif. Metode SAW sering juga dikenal dengan istilah metode penjumlahan terbobot. Konsep dasar metode SAW adalah mencari penjumlahan terbobot dari rating kinerja pada setiap alternatif pada semua atribut. Metode Simple Additive Weighting membutuhkan proses normalisasi matriks keputusan $(\mathrm{X})$ ke suatu skala yang dapat dibandingkan dengan semua rating alternatif yang ada [6]. 
Normalisasi matriks dilakukan dengan cara menghitung rating kinerja dari alternatif dengan cara membagi nilai atribut alternatif dengan atribut yang ada berdasarkan bersamaan yang disesuaikan dengan jenis atribut. Dimana jenis atribut dibagi menjadi duayaitu keuntungan/benefit= maksimum atau biaya/cost $=$ minimum. Apabila kriteria berupabenefit maka nilai atribut kriteria dari setiap kolom dibagi dengan nilai maksimum (Max Xij)dari setiap kolom, begitupun sebaliknya jika nilai atribut cost maka nilai atribut kriteria darisetiap kolom dibagi dengan nilai minimum atribut kriteria (Min Xij) dari tiap kolom.

$$
R i j= \begin{cases}\frac{X i j}{M a x X i j} & \text { Jika } \mathrm{j} \text { adalah atribut keuntungan (benefit) } \\ \frac{M i n X i j}{X i j} & \text { Jika j adalah atribut biaya (Cost) }\end{cases}
$$

Keterangan :

rij = nilai rating kinerja ternormalisasi

$\mathrm{xij}=$ nilai atribut dari setiap kriteria

Max xij = nilai terbesar dari setiap kriteria

Min xij = nilai terkecil dari setiap kriteria

Benefit $=$ jika nilai terbesar adalah terbaik

Cost $=$ jika nilai terkecil adalah terbaik

rij adalah rating kinerja ternormalisasi dari alternatif Vi pada atribut $\mathrm{Ci} ; \mathrm{i}=1,2, \ldots, \mathrm{m}$ dan

$\mathrm{j}=1,2, \ldots$, n. Nilai preferensi untuk setiap alternatif $(\mathrm{Vi})$

$V i=\sum_{j=a}^{n} \mathrm{Wj} \mathrm{rij} \ldots$

Keterangan:

$\mathrm{Vi}=$ ranking untuk setiap alternative.

$\mathrm{Wj}=$ nilai bobot dari setiap kriteria.

rij = nilai rating kinerja ternormalisasi.

Nilai Vi yang lebih besar adalah alternatif yang terpilih.

\section{Tahapan Metode SAW :}

1. Menentukan alternatif $(A i)$ yaitu karyawan sebagai alternatif.

2. Menentukan kriteria-kriteria yang dijadikan pengambilan keputusan $(\mathrm{Ci})$ ada 4 kriteria yaitu kinerja adalahkemampuan karyawan dalam menuntaskan suatu pekerjaan.Kepribadian adalah kemampuan personal dari karyawan. Sosial adalah komunikasi yangdiciptakan oleh karyawan dilingkungan kantor. Profesionaladalah tingkat kemampuan menjaga kerahasiaan data nasabah dari karyawan serta tindakan yang dilakukan pada saat bekerja.

3. Menentukan vector bobot $(W)$ setiap kriteria yaitu kinerja diberi bobot $25 \%$, kepribadiandiberi bobot $25 \%$, sosial diberi bobot $25 \%$ dan profesional diberi bobot $25 \%$.

4. Langkah selanjutnya membuat tingkat kepentingan kriteria, dinilai dari 1 sampai 4.

5. Membuat matriks keputusan berdasarkan kriteria $(C)$, selanjutnya melakukan normalisasimatriks berdasarkan persamaan yang telah disesuaikan sehingga diperoleh matriksternormalisasi (R). 
6. Hasil akhir adalah proses perangkingan penjumlahan dari perkalian matriks ternormalisasi(R) dengan vector bobot sehingga diperoleh hasil nilai terbesar sebagai alternatif terbaik $(A i)$ sebagai karyawan terbaik di PT. Bank Rakyat Indonesia Tbk. Divisi Layanan dan Contact Center Bagian Helpdesk.

\section{HASIL DAN PEMBAHASAN}

Dari hasil penelitian dan pengambilan data di PT. Bank Rakyat Indonesia Tbk. Divisi Layanan dan Contact Center Bagian Helpdeskdiperoleh data kriteria yang dinilai dan pembobotan dari masingmasing kriteria untukpenilaian karyawanterbaik. Data dapat dilihatpada tabel 1.

Tabel 1. Data kriteria dan bobot pemilihan karyawan terbaik

\begin{tabular}{|l|l|l|l|l|}
\hline No & Kriteria & $\begin{array}{l}\text { Sub Kriteria/ } \\
\text { Kompetensi }\end{array}$ & Indikator & Bobot \\
\hline 1 & Kinerja & 7 & $45(6,6,4,11,7,6,5)$ & $25 \%$ \\
\hline 2 & Kepribadian & 3 & $18(5,5,8)$ & $25 \%$ \\
\hline 3 & Sosial & 2 & $6(3,3)$ & $25 \%$ \\
\hline 4 & Profesional & 2 & $9(3,6)$ & $25 \%$ \\
\hline & Total & 14 & 78 & $100 \%$ \\
\hline
\end{tabular}

Dari data kriteria yang ada, terdapat sub kriteria dari setiap kriteria yang akan dinilai dari Bagian Quality Assurance dan penilaian secara langsung oleh Kepala Bagian Helpdesk Divisi Layanan dan Contact Centerdi PT. Bank Rakyat Indonesia Tbk. berupa benefit yaitu sebagai berikut:

1. Kinerja :

- Menguasai produk perbankan

- Perolehat tiket permasalahan

- Absensi

- Kuis bulanan

- Perbaikan data

- Komunikasi dengan unit kerja

- Penilaian dan evaluasi

2. Kepribadian :

- Bertindak sesuai dengan norma agama, hukum, social dan kebudayaan nasional

- Menunjukkan pribadi yang dewasa dan teladan

- Etos kerja, tanggung jawab yang tinggi dan rasa bangga menjadi karyawan

3. Sosial :

- Bersikap inklusif, bertindak obyektif serta tidak diskriminatif

- Komunikasi dengan sesama karyawan

4. Profesional

- Menjaga kerahasiaan data nasabah

- Mengembangkan keprofesionalan melalui tindakan yang reflektif

Hasil dari sub kriteria diperoleh dari penilaian di kantor dengan cara menilai dengan pengamatan dan pemantauan secara langsung oleh penilai yaitu Kepala Bagian. Penilian dinilai dari skala 1, 2, 3 atau 4. Sebelum pemberian nilai skala, penilai terlebih dahulu memberi skor 0,1 atau 2 pada masing - masing indeks dari sub kriteria dan dihitung secara manual oleh Kepala Bagian dengan menjumlahkan hasil penilaian dibagi banyaknya jumlah indeks dikali 2 setelah itu dikalikan dengan $100 \%$, setelah dinilai dan dihitung maka nilai akan dikonversikan kedalam skala. Setelah dinilai dan dihitung maka nilai akan dikonversi kedalam skala seperti table 2.

Tabel 2. Konversi nilai skor ke nilai skala

\begin{tabular}{|l|l|}
\hline Rentang Total Skor & Nilai Kompetensi \\
\hline $0 \%<X \leq 25 \%$ & 1 \\
\hline $25 \%<X \leq 50 \%$ & 2 \\
\hline
\end{tabular}




\begin{tabular}{|l|l|}
\hline $50 \%<X \leq 75 \%$ & 3 \\
\hline $75 \%<X \leq 100 \%$ & 4 \\
\hline
\end{tabular}

Nilai kompetensi dari setiap sub kriteria pada tabel 2 ini yang akan dinilai oleh sistem dengan cara menjumlahkan nilai sub kriteria kemudian dibagi banyaknya sub kriteria. Akan diperolehlah hasil dari setiap kriteria dan akan dihitung dengan sistem menggunakan metode Simple Additive Weighting untuk penyeleksian karyawanterbaik di PT. Bank Rakyat Indonesia Tbk. Divisi Layanan dan Contact Center Bagian Helpdesk.

Untuk menghitung nilai kriteria dari setiap kriteria (Ci) menggunakan aturan sebagaiberikut:

$\mathrm{Ci}=\frac{\text { Jumlah Nilai Kompetensi }}{\text { Banyaknya Kompetens }}=$ Hasil

Keterangan:

$\mathrm{Ci}=$ Nilai Kriteria

Jumlah Nilai Kompetensi $=$ Hasil penjumlahan dari skala 1 sampai 4

Banyak Kompetensi= Jumlah kompetensi yang dinilai pada subkriteria

Hasil akhir berupa jumlah nilai kompetensi dibagi banyak kompetensi. Hasil dari pembagianini akan dijadikan sebagai $\mathrm{Ci}$ untuk nilai kriteria pada alternatif.

\section{Tampilan Aplikasi \\ Halaman Home}

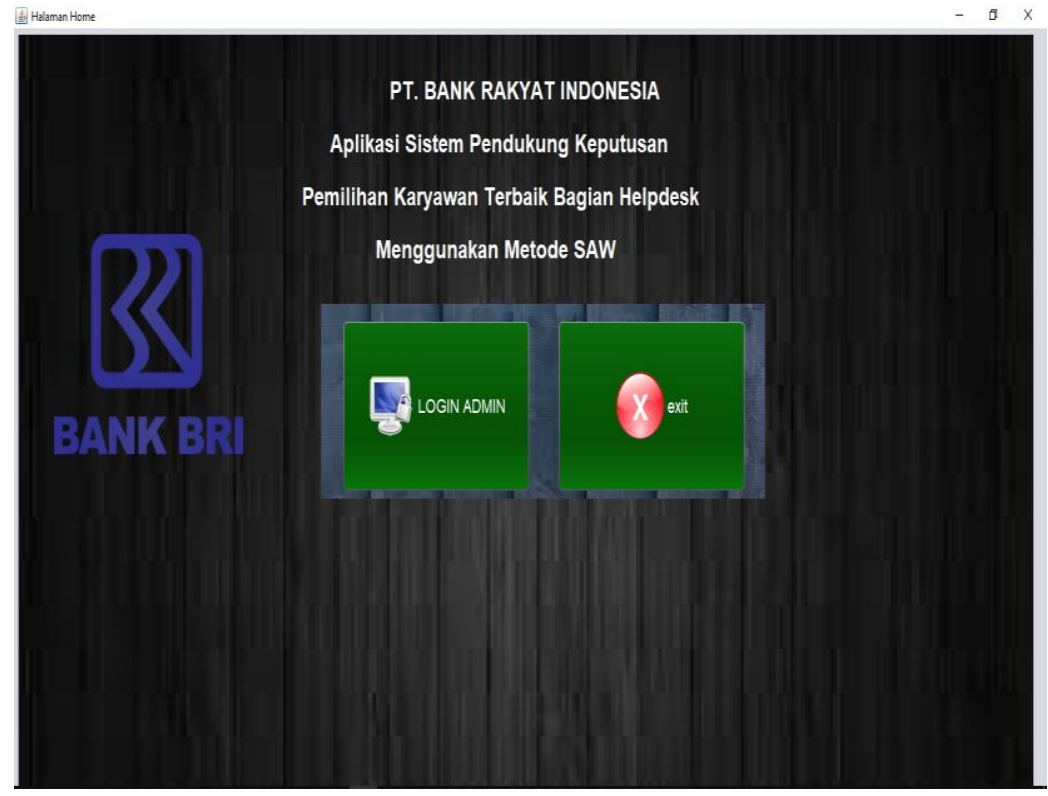

Gambar 1. Halaman Home

Pada Halaman Home terdapat tiga tombol menu yaitu Login Admin dan Exit. Jika tombol Login Admin dipilih maka akan masuk ke halaman Login Admin, jika tombol Garfik Penilaian dipilih maka akan masuk ke halaman Grafik Penilaian, dan jika tombol Exit yang dipilih maka akan menutup jendela aplikasi. 


\section{Halaman Utama}

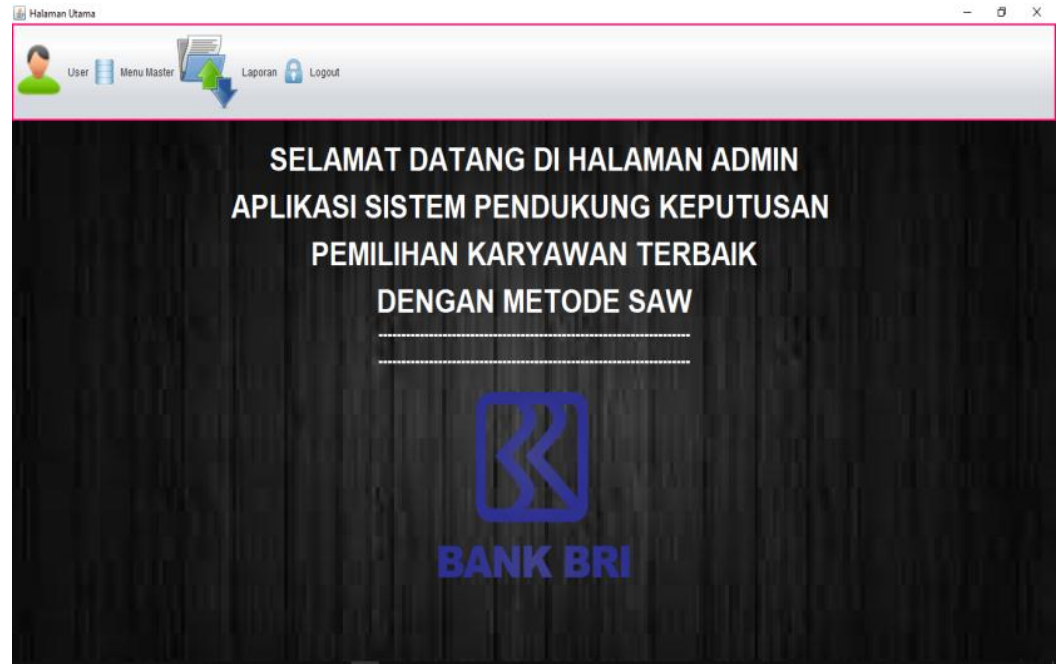

Gambar 2. Halaman Utama

Halaman Utama hanya dapat dikases oleh admin, sebelum mengakses Halaman Utama admin harus dapat berhasil login pada halaman LoginAdmin terlebih dahulu. Menu pada Halaman Utama terdiri dari User, Menu Master dan Laporan. Hanya admin yang dapat memanipulasi data tersebut. Jika mouse diarahkan pada menu User akan ditampilkan item menu Data Admin. Jika mouse diarahkan pada Menu Masterakan ditampilkan item menu Data Karyawan, Data Kriteria, Input Penilaian dan Hasil Penilaian. Jika mouse diarahkan pada menu Logoutakan ditampilkan item menu Logout.

\section{Halaman Data Admin}

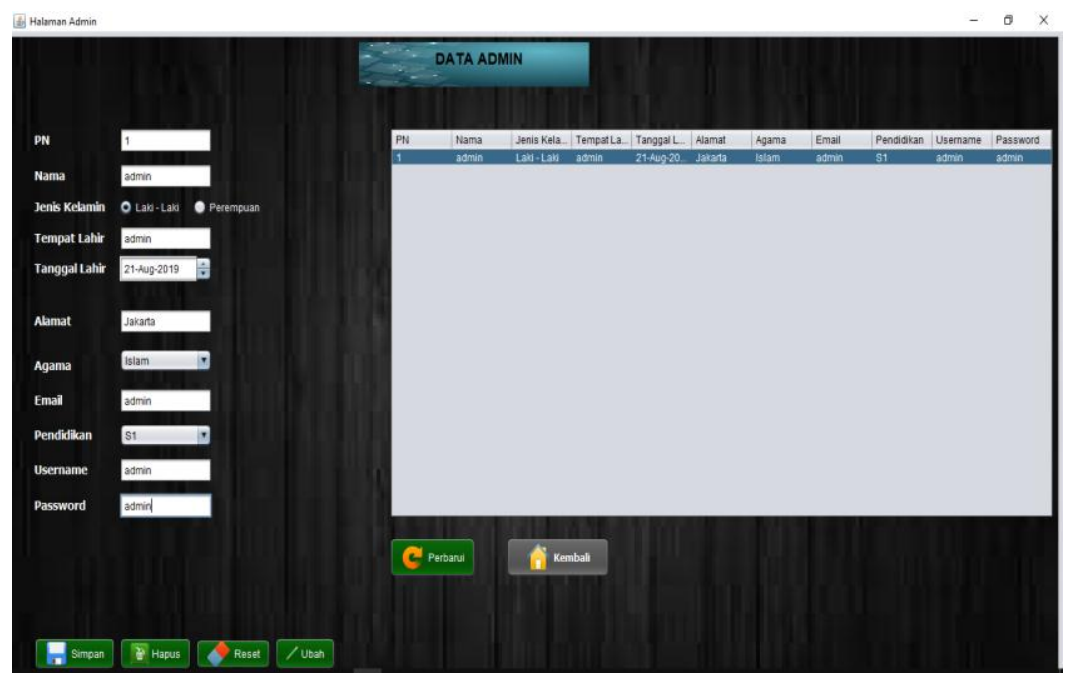

Gambar 3. Halaman Data Admin

Item menu untuk memulai Halaman Admin terdapat pada baris menu User di Halaman Utama. Data admin diisikan pada form admin yang telah disediakan, penulis menggunakan contoh data yang telah diisikan pada form yang terlihat pada gambar 4. Kemudian klik tombol Simpan untuk menyimpan data admin. Klik tombol Ubah, untuk mengubah data admin dan klik tombol Hapus untuk menghapus data admin. Tombol Perbarui untuk menampilkan seluruh data admin yang update ke dalam tabel. Tombol Kembali untuk menutup halaman Admin dan masuk ke Halaman Utama. 
Halaman Data Karyawan

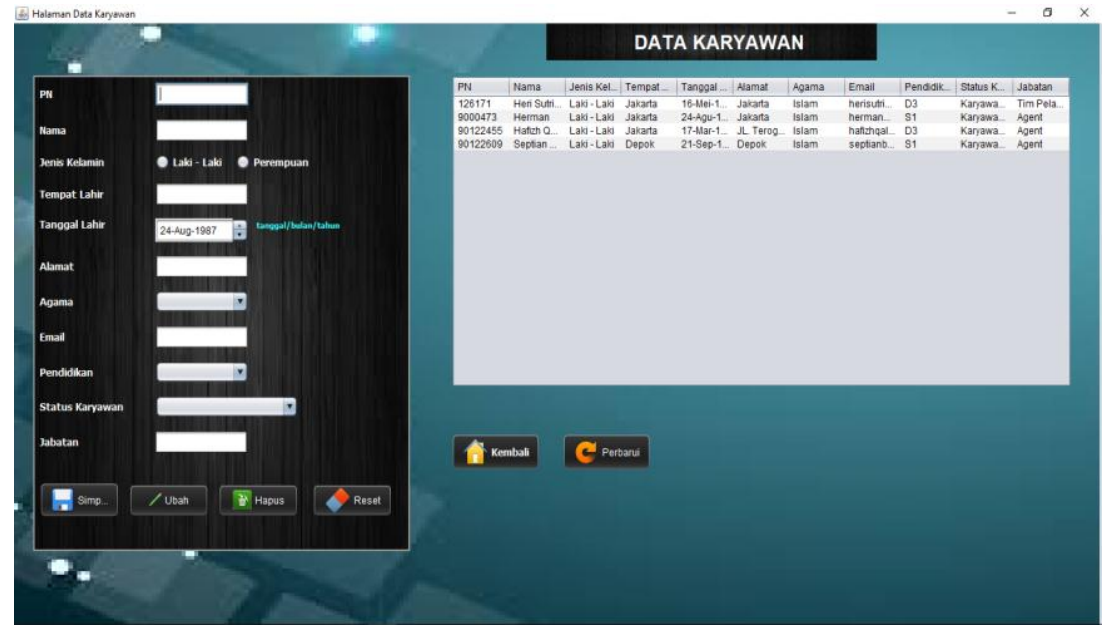

Gambar 4. Halaman Data Karyawan

Untuk membuka halaman Data Karyawan, klik item menu yang terdapat pada baris menu Menu Master di Halaman Utama. Isikan data Karyawan secara lengkap sesuai dengan form yang telah disediakan, penulis menggunakan contoh data yang telah diisikan pada form yang terlihat pada gambar 5. Kemudian klik tombol Simpan untuk menyimpan data Karyawan yang telah diisikan. Klik tombol Ubah untuk mengubah data Karyawan, klik tombol Hapus untuk menghapus data Karyawan dan atau klik tombol Reset untuk mengosongkan data Karyawan. Klik tombol perbarui untuk menampilkan seluruh data Karyawan yang update. Tombol Kembali untuk menutup halaman Data Karyawan dan masuk ke Halaman Utama.

\section{Halaman Input Penilaian}

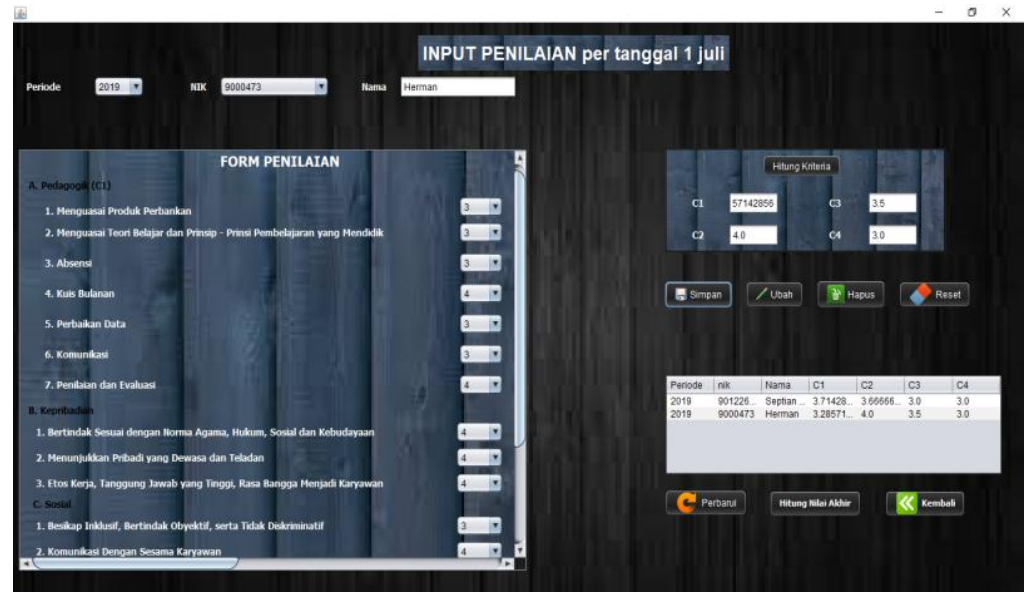

Gambar 5. Halaman Input Penilaian

Untuk membuka halaman Input Penilaian, klik item menu Input Penilaian yang terdapat pada baris menu Menu Master di Halaman Utama. Sebelum mengisikan nilai harus menentukan periode penilaian, dengan memilih periode pada form yang telah disediakan. Kemudian, mengisi penilaian pada Karyawan yang telah dipilih berdasarkan PN dan Nama pada form yang telah disediakan. Penulis menggunakan contoh data yang telah diisikan pada form yang terlihat pada gambar 7. Kemudian klik tombol Simpan untuk menyimpan data penilaian yang telah diisikan. Klik tombol Ubah untuk mengubah data penilaian, klik tombol Hapus untuk menghapus data penilaian dan atau klik tombol Reset untuk mengosongkan data penilaian pada form. Klik tombol perbarui untuk menampilkan seluruh data penilaian yang update. Klik tombol Hitung Nilai Akhir untuk menutup halaman Input Penilaian dan masuk ke Halaman Hasil 
Penilaian. Klik tombol Kembali untuk menutup halaman Input Penilaian dan masuk ke Halaman Utama.

\section{Halaman Hasil Penilaian}

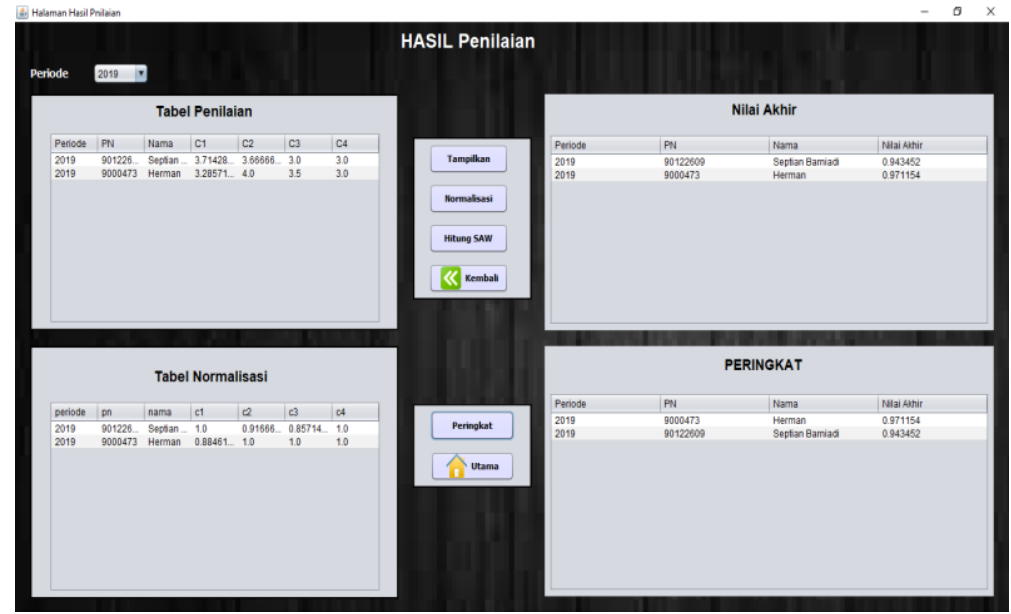

Gambar 6. Halaman Hasil Penilaian

Untuk membuka halaman Hasil Penilaian, klik item menu Hasil Penilaian yang terdapat pada baris menu Menu Master di Halaman Utama. Sebelum melihat hasil penilaian, pilih periode penilaian pada form combobox yang telah disediakan. Hasil penilaian ditampilkan berdasarkan periode penilaian. Kemudian, klik tombol Tampilkan untuk menampilkan data penilaian berdasarkan periode yang telah dipilih. Klik tombol Normalisasi untuk melakukan normalisasi nilai dari dari data penilaian. Selanjutnya, klik tombol Hitung SAW untuk menentukan nilai akhir penilaian dan klik tombol Peringkat untuk menKaryawantkan hasil akhir penilaian secara ascending. Kemudian klik Tombol Kembali untuk menutup halaman Hasil Penilaian dan masuk kembali ke halaman Input Penilaian, atau klik Tombol Utama untuk menutup halaman Hasil Penilaian dan masuk ke Halaman Utama. Penulis menggunakan contoh data yang ditampilkan pada form yang terlihat pada gambar 8 .

\section{Halaman Cetak Data Karyawan}

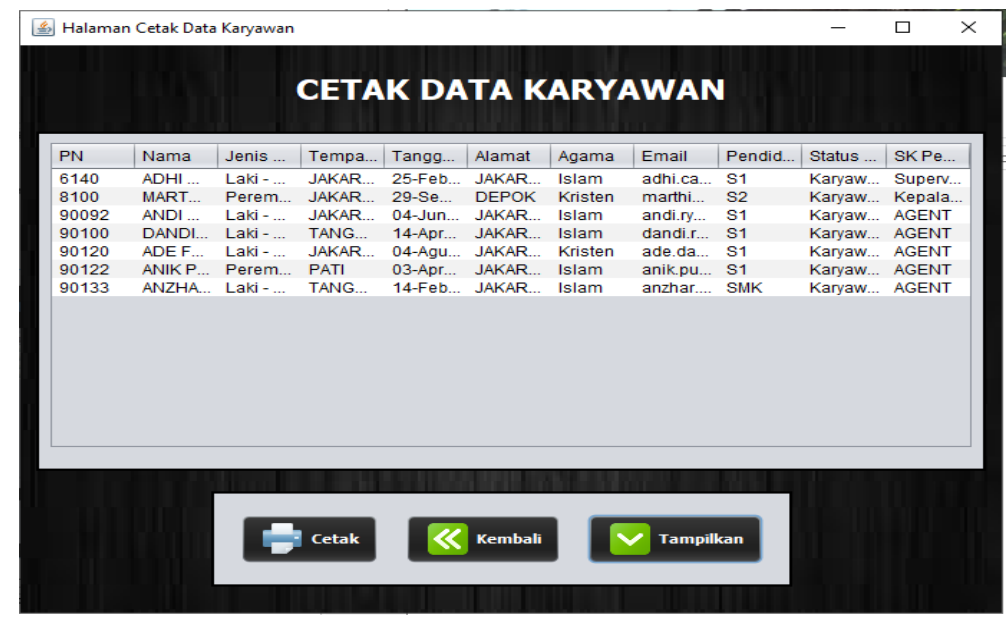

Gambar 7. Halaman Cetak Data Karyawan

Untuk membuka halaman Cetak Data Karyawan, klik item menu Cetak Data Karyawan yang terdapat pada baris menu Laporan di Halaman Utama.Klik tombol Tampilkan untuk menampilkan data Karyawan pada tabel. Klik tombol cetak untuk memulai mencetak data Karyawan. Klik tombol Kembali untuk menutup halaman Cetak Data Karyawan dan masuk ke halaman Utama. Penulis menggunakan contoh data yang ditampilkan pada tabelyang terlihat pada gambar 9 . 
Berikut adalah gambar tampilan output dari tombol Cetak.

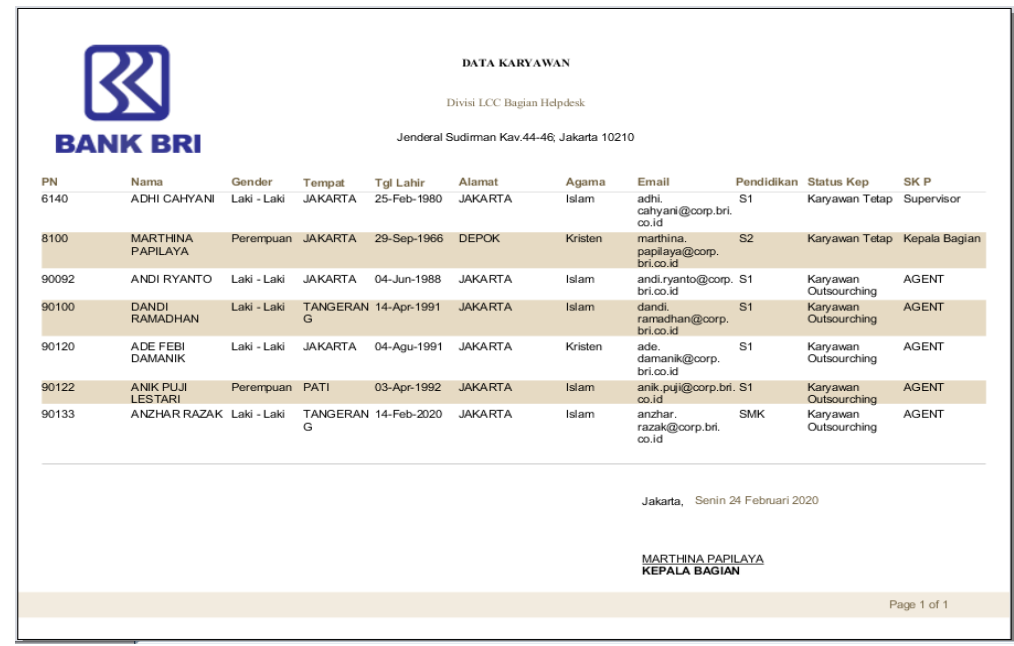

Gambar 8. Hasil Cetak Data Karyawan

\section{Halaman Hasil Penilaian}

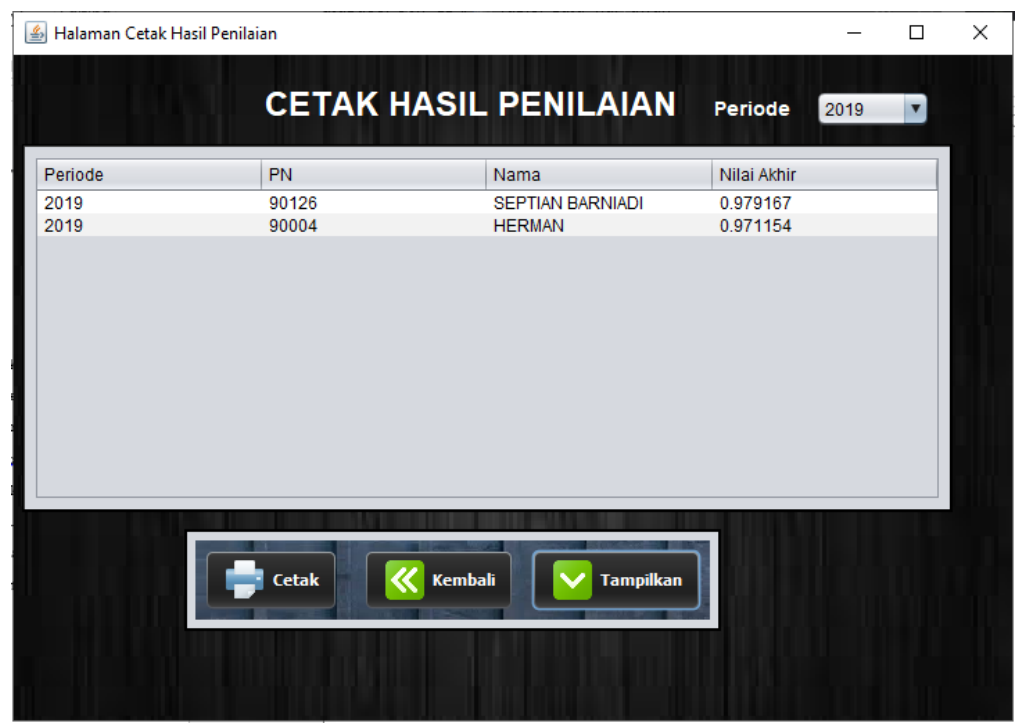

Gambar 9. Halaman Cetak Data Penilaian

Untuk membuka halaman Cetak Hasil Penilaian, klik item menu Cetak Hasil Penilaian yang terdapat pada baris menu Laporan di Halaman Utama. Klik tombol Tampilkan akan menampilkan data penilaian pada tabel. Pilih periode penilaian yang akan dicetak pada combobox Periode sebelum memilih tombol Cetak. Klik tombol Cetak untuk memulai mencetak hasil penilaian. Klik tombol Kembali, untuk menutup halaman Cetak Hasil Penilaian dan masuk ke Halaman Utama. Penulis menggunakan contoh data yang ditampilkan pada tabelyang terlihat pada gambar 15. 
Berikut adalah gambar tampilan output dari tombol Cetak.

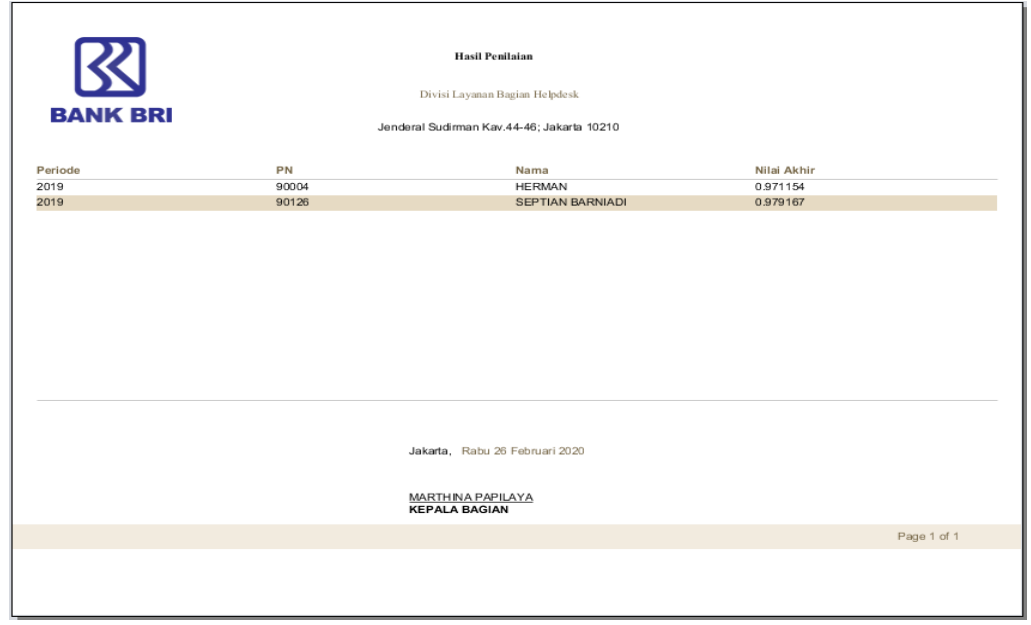

Gambar 10. Hasil Cetak Data Penilaian

\section{SIMPULAN}

Aplikasi sistem pendukung keputusanpemilihan karyawan terbaik dengan metode simple additive weighting ini dapat menentukan karyawan terbaik pada PT. Bank Rakyat Indonesia Tbk. Divisi Layanan dan Contact Center Bagian Helpdesk.secaracepat, tepat dan efisien.berdasarkan dari masing-masing bobot kriteria yang telah ditentukan. Aplikasi ini juga sangat mudah untuk digunakan.

\section{DAFTAR PUSTAKA}

[1] E. L. Ruskan, "Kolaborasi Metode Saw Dan Ahp Untuk Sistem Pendukung Keputusan Penilaian Kinerja Asisten Laboratorium," JSI J. Sist. Inf., vol. 9, no. 1, pp. 1204-1215, 2017.

[2] I. Setiadi, "Sistem Pendukung Keputusan Pemilihan Mobil Bekas Dengan Metode AHP dan SAW Pada Nava Sukses Motor," J. String, vol. 3, no. 3, pp. 247-257, 2019.

[3] A. F. Mustofa and M. I. Majaruni, "Sistem Pendukung Keputusan Penilaian Kinerja Guru Menggunakan Metode Simple Additive Weighting," CAHAYAtech, vol. 7, no. 1, p. 1, 2019.

[4] S. Abadi and F. Latifah, "Decision Support System Penilaian Kinerja Karyawan Pada Perusahaan Menggunakan Metode Simple Additive Weighting," J. TAM (Technology Accept. Model., vol. 6, pp. 37-43, 2016.

[5] F. Atika, "Sistem Pendukung Keputusan Pemilihan Guru Berprestasi Di Kecamatan Kradenan Kabupaten Grobogan Menggunakan Metode Simple Additive Weihting," 2017.

[6] Rudianto \& Haryanto, "Implementation Of The SAW Method For Selection Of Best Operational Vehicles," JITE (Journal Informatics Telecommun. Eng., vol. 4, no. 1, pp. 112-118, 2020. 